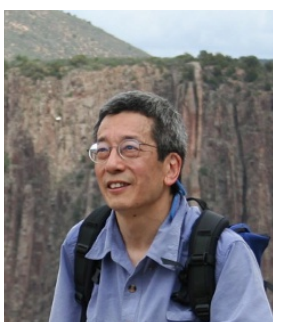

\title{
Roger Y. Tsien
}

\section{2-2016}

\author{
Amy E Palmer \& Jin Zhang
}

\section{Roger Tsien left us on August 24. His untimely passing has saddened and shocked the scientific community. Roger literally and figuratively brightened our world, illuminated the dark matter of biology, and forever changed our view of the interface of chemistry and biology.}

A $s$ a chemist and self-proclaimed molecular engineer, Roger loved to make molecules, and his name is forever imprinted in some of them-Fura2, GFP, the cameleons. As he recounted in his Nobel biography, he routinely experimented in the basement of the family house as a young boy, trying to burn red phosphorus in a stream of chlorine gas to make a necessary reactant! As an undergraduate at Harvard, Roger majored in chemistry and physics, but his curiosity veered toward neuroscience. Fascinated by the brain, Roger went to Cambridge to earn his PhD studying neurobiology. In his independent career, Roger served on the faculty at the University of California, Berkeley, before moving in 1989 to the University of California, San Diego, where he was a professor of pharmacology, chemistry and biochemistry and a Howard Hughes Medical Institute investigator.

His drive to see the brain at work, and the activity of many neurons firing in parallel, is what led him down the path toward designing and synthesizing new dyes to visualize neuronal activity. Roger tinkered with the structure of EGTA, leading to the first major breakthrough of his career: the creation of a new chelator and indicator, BAPTA, that bound $\mathrm{Ca}^{2+}$ selectively over $\mathrm{Mg}^{2+}$ and that would serve as the backbone for a generation of $\mathrm{Ca}^{2+}$ indicator dyes (Fura-2, Indo-1, Fluo-3) that are still in use today. Roger's $\mathrm{PhD}$ thesis, entitled "The design and use of organic chemical tools in cellular physiology," foreshadowed an amazing career marked by countless contributions and a series of molecular Hall of Famers: fluorescent $\mathrm{Ca}^{2+}$ indicators, photolabile caged signaling ions and molecules, genetically encoded sensors, probes for correlative light and electron microscopy, and of course the work for which he shared the Nobel Prize in Chemistry in 2008, the development of green fluorescent protein (GFP) and other fluorescent protein variants into the powerful and ubiquitous tools they are today. These molecules, engineered to 'spy on cells', have made it possible to track nearly every biochemical event in living systems and have revolutionized neurobiology and cell biology.

Years after his initial exploits leading to the development of $\mathrm{Ca}^{2+}$ indicator dyes, Roger would continue to explore making molecules, taking over a chemical hood in his laboratory for two weeks each year during Christmas vacation. Former and current members of his lab fondly recall how these experiments would inevitably result in a number of round-bottom flasks with questionable contents and would bring out Roger's characteristic mischievous smile and wry sense of humor as he presented his successes and failures at the first group meeting in January.

Roger was a pioneer in every sense of the word. He was a trailblazer in the development and application of chemical tools to probe and study biology before chemical biology had entered the popular scientific lexicon. He was an incessant explorer, driven by his insatiable thirst for knowledge and zeal for discovery, which led him to break new ground over and over again. And he helped colonize the community of live-cell fluorescence imaging by creating and popularizing tools for visualizing biological processes. Roger often recounted how biologists rejected him as a chemist and chemists rejected him as a biologist. His ability to make simple molecules and apply chemical principles to them-for example in recognizing that a successful $\mathrm{Ca}^{2+}$ indicator would need to achieve selectivity over $\mathrm{Mg}^{2+}$, which was orders of magnitude more abundant in cells, or in discovering the chemical mechanism of chromophore formation in fluorescent proteins that allowed him to manipulate and control this process-and his ability to gracefully bridge both communities are arguably why Roger had such a profound impact. Although Roger is best known for the tools he developed, he was deeply motivated by understanding the underlying mysteries of biology. He built molecules not as ends in and of themselves, but as means to probe biology, to answer questions that couldn't be tackled with existing tools.

Roger's visions and insights were ahead of his time, yet his genius is reflected in his straightforward approach. Roger's advice to graduate students and postdocs was often to find simple solutions to challenging problems. His lasting legacy is the simplicity and beauty of the tools he developed-tools that have provided an unparalleled glimpse into the inner workings of cells.

Roger was full of warmth, humor, and of course color; he loved anything that added beauty to his world-music, photography, romance. He appreciated the complexity and simplicity of nature, and his ingenious creation of molecules was often inspired by nature. $\mathrm{He}$ was an adventurer and loved to explore, both in life-biking and hiking — and in science. He was driven by pure curiosity and love of knowledge. Our world is forever changed by the many treasures he left behind. For those who knew Roger or were the beneficiaries of his many contributions to science, it felt as if a little color, a little humor, and a little warmth had disappeared with his departure.

Roger didn't like to dwell on his accomplishments; if he were here he would reach forward and advance the slides, pushing the conversation into a new direction. So perhaps that's why his departure is felt so acutely: in his absence we are forced to pause and reflect on the profound influence of this incredible man on the scientific community, the world around us, and indeed our own lives.

Published online 26 September 2016 http://dx.doi.org/10.1038/nchembio.2213

Amy E. Palmer is at the Department of Chemistry and Biochemistry, University of Colorado, Boulder, Colorado, USA. Jin Zhang is at the Department of Pharmacology, University of California, San Diego,

La Jolla, California, USA.

e-mail:amy.palmer@colorado.edu or

jzhang32@ucsd.edu 